\title{
TRANSGENIC PLANTS: REVIEW ON RISKS AND BENEFITS IN THE ENVIRONMENT OF DEVELOPING COUNTRIES
}

\author{
Umesh Prasad Shrivastava \\ Department of Botany
}

\begin{abstract}
Various transgenic plants have been produced employing various techniques. These plants perform interaction among other organisms the agro-environment. But, cultivation of these plants is a matter of debate. Various questions on risk factors have been raised by many authors, e.g. problems related consequences of gene escape, adverse impact on biodiversity, natural enemies, pollinators, soil organisms, decomposers and various non target organisms. On the other hand, various supporters give emphasis in the favour of transgenic plants praising its benefits, e.g. reduced environmental impact from pesticides and insecticide, increased yield, soil conservation, phytoremediation etc. Critical analysis of this controversy is the main concern of this present mini review. Also, an attempt has been made to describe the potential impact of transgenic plants in developing countries.
\end{abstract}

\section{Keywords}

Transgenic plants, genetically modified organisms, risks, benefits, developing countries

\section{Introduction}

Transgenic organisms, also called as Genetically Modified Organisms (GMO), are generally produced by applying the techniques of genetic engineering or modification of genetic materials of crops (Skerritt, 200o). The modification can most simply be defined as the transfer of genetic material from a different species (plant, bacterial or animal) or from a chemically synthesized gene into a target plant. The first successful genetic engineering of a plant was reported in 1983. Broad-leafed plants such as tobacco and tomato were transformed easily, and reliable transformation of cereals such as rice and maize were not reported 
until the late 1980s. Reliable transformation of barley and wheat only commenced in the mid- 1990s (Skerritt, 2000). Genes (as parts of chromosomes rather than individual genes) have been spontaneously transferred from grasses such as Agropyron into wheat and the derived varieties used for human food with no controversy. Other techniques such as use of plant tissue culture, induced mutations, doubled haploids and F1 hybrids also involve interference with natural breeding but have not raised controversy. The distinguishing feature of genetically modified plants is the targeting of the genes to be used and the fact that the target gene is not restricted to being in the same species. Indeed, the potential to be able to use human or animal genes in plants was earlier utilized by scientists as an example of the potential of the technology. However, it is likely that use of these examples had negative impact on public perceptions of genetic engineering. This review focus on the risks and benefits explained by the scientists working in this field, various controversies have been put forwarded for/against the use of transgenic crops by human beings. The impact of transgenic plants for the people of developing countries has been critically analyzed.

\section{The present status of field-grown transgenic crops}

The commercial plantation of first transgenic crops were started in 1995 and by 2000, a total of 44.2 million ha of transgenic plants were grown in 13 countries (James, 2001). The use of this technology increased only an $11 \%$ over the area in 1999 and by 2000 spread very rapidly $(84 \%)$ in the developing countries. World-wide, most transgenic crops are grown in developed countries ( $76 \%$ of total area) and $24 \%$ in developing countries. Most of this area is divided among four crops, soybean (58\%), maize $(23 \%)$, cotton $(12 \%)$ and oilseed rape (7\%). The area devoted to transgenic soybean and cotton increased since 1999, but that of maize and oilseed rape decreased (James, 2001). Though a wide array of traits has been inserted into many species of plants, in which only a few in commercial cultivation, mostly herbicide resistance and insect resistance. In $2000,74 \%$ of all transgenic crops were herbicide resistant, $19 \%$ insect tolerant and a further $7 \%$ contained both these traits. Herbicide resistant soybean was the most widely planted transgenic crop (59\% of the global area devoted to transgenic crops), with insect-resistant maize a distant second (15\% of global area). At present, there is a lack of precise, justified legal framework that hinders assessment, potential commercial application and evaluation of this technology. When the industry developing transgenic plants has been required to assess the potential environmental consequences of their products, the results have not been impressive (Purrington and Bergelson, 1995). There is clearly a need for a conceptual framework and more involvement of ecologists.

\section{Assessment of environmental risk in ecological framework}

It is realized these days that agricultural fields are also a part of the "ecological theatre" in which the "evolutionary play" is continuously being played (Hutchinson, 1965). When transgenic plants are planted in the field, they interact with many other species growing around in the environment and perform several ecological processes in agricultural fields. Quit natural, these plants are natural "actors" playing important role in this "ecological theatre." There role which are being played together with the transgenic plants, raise a number of questions, which are mentioned below.

Herbivores that feed on plants above or below ground. How affects on non-target herbivores (and biodiversity)?

Other plants, whether conspecifics or individuals of other species. What about invasiveness and gene transfer?

Natural enemies of these organisms. What are the consequences for natural pest control? 
Pollinators that visit their flowers. What are the potential consequences for pollinating insects?

Symbionts that live in the root zone, such as mycorrhizae or nitrogen-fixing bacteria. How they interact?

Detritivores and decomposers that feed on dead plant parts. How does this affect the soil ecological processes maintaining soil fertility, nutrient cycling and plant growth?

\section{Effects on biodiversity}

In the region of intensive agriculture, especially in the Northern Hemisphere, agriculture is a significant environmental management factor, and much of biological diversity of those countries exists in a cultivated landscape (Krebs et al., 1999). Alteration in the current management regime has potentially significant consequences for biological diversity in such countries.

Herbicide-resistant crops are expected to allow more efficient weed control. Objections have been initiated, especially in the United Kingdom, which emphasis the negative consequences for biological diversity in the countryside. Explanations are put forward for fewer surviving flowering plants to provide resources for organisms ranging from invertebrates to birds. The possible effects of such a scenario were approximated by modelling (Watkinson et al., 200o). They argue by model of weed (Chenopodium album) and a songbird (skylark, Alauda arvensis) in a landscape to predict the effects of herbicide resistant sugarbeet on biological diversity in general. Their work points to potentially significant negative effects on seed-eating birds. Similar concerns prompted the U.K. government to ban commercial growing of transgenic plants and initiate a 4-year farmscale field trial to study what effect herbicide resistant transgenic plants will have on biodiversity (Firbank et al., 1999). Studies published so far on the effects of transgenic plants on agricultural biodiversity are rather imperfect (Hilbeck et al., 200o).

\section{Consequences of gene escape / invasiveness}

Gene escape has been recognized as a potentially significant hazard (Wolfenbarger \& Phifer, 200o). It may result in to possible out-crossing and hybridization with wild relatives (Elstrand et al., 1999). The ecological consequences of this could be serious if the new trait changes fitness parameters or invasiveness of the modified plants. Invasiveness has been recognized as a major threat in New Zealand, but invasions are also concerned to whole world (Vitousek et al., 1997a). Data related to fitness or invasiveness of genetically modified plants is rare. The oilseed rape containing the Bt-toxin gene acquires a fitness advantage under insect herbivory (Stewart et al., 1997). In a long-term study of survival in the wild and invasiveness of herbicide-resistant crop plants in different area of the British Isles, nogenetically modified plant line survived longer than 4 years when planted in natural habitats (Crawley et al., 2001). However, invasion success is scalerelated, and it is rather difficult to predict the consequences of wide-scale planting of transgenic crops from limited-scale studies.

\section{Effects on natural enemies}

Insect-resistant plants are targeted at reducing the densities of certain insects feeding on plants. These insects, however, also serve as prey for a range of natural enemies. An important potential effect of transgenic plants is the consequences of changing the occurrence and density of prey for natural enemies. If the density of prey is reduced, a direct flow-on effect could be a reduced density of their natural enemies. Transgenic potato controlling the Colorado potato beetle is probably responsible for a documented decrease of its specialist predatory ground beetle (Riddick et al., 1998). 
Predatory and parasitoid insects are also sensitive to quality of their prey at one side and other side host plants determine the quality of prey; thus, tri-trophic interactions exist in the crop field (Price et al., 1980). A lot of such examples have been recognized in the environment of transgenic plants or their experimental equivalents. Such as, the parasitoid wasp Eulophus pennicornis had reduced parasitic ability on tomato fruit-worm (Lacanobia oleracea) hosts from plants with the cowpea trypsin inhibitor (Bell et al., 2001). Parasitoids can also react at a behavioural level to a host originating on transgenic plants (Schuler et al., 1999).

Adults of the ladybug, when fed on aphids raised on transgenic potato (expressing the snowdrop lectin), were negatively affected. Adult female (but not male) longevity was reduced, egg laying and egg viability decreased (Birch et al., 1999). Interestingly, larvae of the same ladybug did not seem to suffer the same consequences (Down et al., 2000).

In another case, adult ground beetles consumed less of their caterpillar prey when this prey was raised on proteinase inhibitorcontaining diet vs. normal diet. This effect persisted longer than the actual exposure to the manipulated prey and was age-dependent (Jørgensen \& Lövei, 1999). Proteinase inhibitors seem to affect herbivore suitability as prey for this predator.

\section{Effects on pollinators}

More than $25 \%$ of the world's foods crops are pollinated by animals. Pollinating organisms in the temperate regions are mostly insects, namely bees and wasps (Buchmann \& Nabham 1996). They can be agents of pollen spread and exposed to any transgenic product that is expressed in pollen or nectar. Bees and bumble bees can be affected by transgenic products (Malone et al., 2001); thus, the systematic study for the environmental risk assessment of transgenic plants seems essential which can insure us that ecosystem service is not being damaged (Lövei et al., 2001).

\section{Effects on soil organisms and decomposers}

The Bt-toxin has been reported in root exudates of transgenic Bt-maize, their concentration is sufficient to kill insects, (Saxena et al., 200o). Their long-term consequences are still unknown. Transient effects and significant changes have been reported in soil protozoan populations in soil under genetically engineered potato lines (Griffiths et al., 200o). The maintenance of soil fertility depends on biological process, tests of the effects of transgenic plants on soil processes are very important.

Many of these actors participate in ecological processes that are useful and necessary for agricultural production. These processes are termed 'ecosystem services' (Lövei, 2001). This framework of 'ecosystem services' would be useful in order to conceptualize the environmental risk assessment of transgenic plants.

\section{Effects on non-target organisms}

Organisms feeding on plants were not targeted may still be affected by insectresistant plants. For example, transgenic maize pollen, deposited on milkweed leaves could cause larval mortality of the monarch butterfly (Danais plexippus) (Losey et al.., 1999), which is a species of important nature conservation focus in the U.S.A. This study engendered a number of others, indicating that natural pollen concentrations can still cause significant mortality (Hansen Jesse and Obrycki, 200o). Larvae of the black swallowtail (Papilio polyxenes) are not sensitive to transgenic maize pollen (Wraight et al., 2000).

\section{Potential ecological benefits}

The evaluation of the environmental impact of transgenic organisms often centres on the risks attached to them. This is justified, as any new, large-scale technology does have risks and unforeseen consequences. However, 
a number of arguments have suggested a positive environmental impact from largescale production of transgenic plants (Wolfenbarger and Phifer, 200o).

\section{Reduced environmental impact from pesticides}

Herbicides and pesticides have potential hazards for environmental pollutions, whereas, transgenic crops may decrease the use of environmentally harmful chemicals to control weeds and pests. (Wolfenbarger and Phifer, 200o). For example, reduced frequency of treatments can bring a net decrease in pesticide pollution if paralleled with a decrease in the total amount of pesticide and herbicide used. Conflicting claims have been made about the effect of herbicidetolerant crops in the U.S.A. (Carpenter and Gianessi, 200o). In the absence of published documentation where the assumptions and the validity of the arguments can be checked, no conclusions can be drawn (Wolfenbarger and Phifer, 2000).

\section{Increased yield}

If crop yields increased, less cultivated area would be needed to produce the total amount of food required by people. This could result in a lower pressure on land not yet under cultivation and could allow more land to be left under protection. The potential environmental benefits of this type may be greatest in developing countries where most of the agricultural production increase was due to new areas taken into cultivation.

\section{Soil conservation}

Herbicide-tolerant crops may allow farmers to abandon the use of soil-incorporated pre-emergent herbicides. This shift to postemergent weed control may increase the no-till and conservation tillage practices, decreasing soil erosion, water loss, and increasing soil organic matter (Cannell and Hawes, 1994).

\section{Phytoremediation}

Emphasis has been given for in situ remediation of soil and water pollution by transgenic plants and micro-organisms. Transgenic plants can sequester heavy metals from soils (Gleba et al., 1999) or detoxify pollutants (Bizily et al., 200o). This has not yet been used widely, so its environmental impact has not been studied.

\section{Potential impact in developing countries}

China is the first country to grow transgenic crops on a commercial scale, virus resistant tobacco and tomatoes (Skerritt, 200o). China is now only a relatively modest producer of $B t$ cotton; the proportion of genetically modified crops in China as a proportion of those world wide is decreasing. This is not due to Government influence in China, but rather because seed distribution and vertical integration of seed sales through to crop marketing are far better developed in the Western countries. From a technical standpoint, the use of transgenic plants could have substantial benefits for developing countries. These may include increased disease and pest resistance, increased yields, crops with higher nutrient content and delivery of vaccines. Higher lysine maize and bananas carry vaccines have already been engineered. There is potential, as yet unrealized, for genetic engineering to assist those in developing countries who did not benefit from the "Green Revolution", especially farmers in rain-fed marginal lands. Genetic engineering could enhance the ability of crops to be resistant to soils with high levels of salt, acidity or toxic elements such as aluminium or boron. Drought resistance is a difficult phenotype to manipulate, but advances are being made in conventional breeding and in some cases gene identification. For example, the international wheat and maize centre, CIMMYT has made significant advances using conventional breeding in developing drought resistant maize genotypes. Genetic engineering has the ability to enhance 
the ability for legumes to fix atmospheric nitrogen with the potential for crops such as cereals to also fix nitrogen. This would decrease the need for often expensive and imported fertilizers. Enhancement of storage qualities and transportability of perishable crops through genetic modification could be especially important for developing nations. However, the main benefits in the major crop, rice, could still dwell ahead, with rice blast resistance, stem borer resistance using $B t$ and herbicide tolerance being actively developed. Rising rice demand will not be met because of limited rice cultivation areas and rapid population expansion. Dr Ronald Cantrell, Director-General of the International Rice Research Institute, estimated that by year 2025, the population in Asia will increase by 1-1.5 billion and need $60 \%$ more rice than in 1995. Bt rice, developed through the Asian Rice Biotechnology Network underwent major field trials in China in 1998. Currently \$10oo $\mathrm{m}$ annually is spent on insecticidal control in rice in Asia alone (Krattiger, 1997). One of the greatest challenges will be in delivery of the technology to developing countries since there is often a poorly-developed seed industry. However, the fact that "Green Revolution" cereal varieties were relatively rapidly adopted in an era when infrastructure and transport were poorer is encouraging for future seed distribution. But are the crop genetic improvements that are currently available suitable for developing countries? Recently, sweet potato, a developing country crop, was engineered for improved protein quality (Moffat, 1998). A troubling situation for developing countries is that some of the products of genetic engineering have the potential risk of displacement which currently has lucrative export markets in developing countries. For example, coconut oil is naturally high in lauric acid, useful for soaps, detergents, margarine and cooking oil. It is especially central to Philippines agriculture, but is also important in Indonesia, Malaysia and India. Its major competitor, palm oil, is central to the Malaysian economy. However, both are now under challenge from highlauric acid transgenic canola oil (Murphy, 1996), and canola is suited for growth in temperate developed countries. Transgenic crops that require capital investments such as aerial sprays and irrigation and/or may reduce labour needs could have poor adoption and fuel unemployment in developing countries. Other concerns include that the cost of accessing the technology may be too high, as transgenic crops are one of the greatest areas of commercial involvement in agriculture, and are dominated by US- and European-based multinationals. There are also broad patents (broad in both the terms of technology covered and geographical coverage) granted to these multinational companies. These not only cover specific crop products, but enabling technologies such as use of Agrobacterium vectors for transformation. Developing countries may not have access to technology at affordable prices. Several of the multinationals are reluctant to operate in developing countries as they perceive that their intellectual property may not be sufficiently secure. More importantly, biotechnologists in developing countries scientists in they may have their freedom to operate taken away. There is thus a rather spirited debate on whether transgenic crops will contribute to food security in developing countries or lead to food insecurity, and many of the same public acceptance concerns remain valid (Aerni, 1999). In addition, is crop genetically modified appropriate technology for developing countries or should the focus be on standard breeding, agronomy and extension to improve yields, quality and reduce post harvest losses? The inability to resow seed in many of the commercial contracts established in the west is of particular concern. Terminator technology (more correctly known as Gene Use Restriction Technology (GURT) refers to a set of genetic switches that can be activated in transgenic crops to ensure that the grain is not useful as seed. While this is intended to ensure that the purchaser of the technology cannot avoid paying for 
its potential advantages through regular purchase of seed, it commits the farmer to regular outlays that may not be achievable. It is of interest that the Consultative Group for International Agricultural Research (CGIAR) and several other international groups have criticized GURT from an ethical standpoint, and banned its use in CGIAR breeding programmes (CGIAR, 1998). While it can be argued that the technology has advantages in preventing escape of transgenes to wild relatives, a starving developing country farmer could not re-sow their seed in a famine year. It is fair to say that this debate is still active within many R\&D organizations in developing countries and within donor agencies. The ICGEB (International Centre for Genetic Engineering and Biotechnology) have a focus on research and training in molecular biology and biotechnology, emphasising developing country needs and safe use of biotechnology. IFPRI (International Food Policy Research Institute) carries out research on the implications of biotechnology and biotechnology policy for poverty alleviation in developing countries. There are various agencies to monitor and evaluate the availability of biotechnology, including genetically modified crop technology, for transfer to developing countries. They focus on horticultural crops (as there are economic structures that can absorb the higher-value commodities), non-commercial crops grown by poor farmers, and forestry. They have commissioned CAMBIA (Centre for Application of Molecular Biology in International Agriculture) to develop a database which will indicate the ownership of technologies, an important issue in determining whether scientists in particular countries have "freedom to operate" in manipulation of certain crops. BINAS (Biotechnology Information Network and Advisory Service) is an information initiative of UNIDO (United Nations International Development Organization). It also serves as a central clearinghouse for information of biotechnology regulations in different countries.

\section{Conclusion}

In conclusion, the evaluation of the environmental effects of transgenic plants should include the study of beneficial ecological interactions seems essential. The significance of conceptualization of the study on "ecosystem services" as it links this question to one of the most important intellectual concepts of current ecology. This was borne by the necessity to convey the realization that human impacts on ecosystems are global and profound (Vitousek et al., 1997b), and we need to use a unified conceptual approach to interpret them. If transgenic technology causes significant harm to these ecological services, we are heading the wrong way. There is too little resilience left in the natural ecosystems to absorb continued abuse.

However, assessing the impact of this technology does not have to be conducted with the mindset of "averting damage". The arguments regarding possible benefits of transgenic plants are plausible, but so far all of them are insufficiently documented (Wolfenbarger \& Phifer 200o). They need to be incorporated into the environmental impact of this technology. It is important to stress that the total environmental impact should be measured against current practice, and not against an idealised but non-existing agricultural cultivation system.

In the context of developing countries, we can conclude that the realization of beneficial aspects are more important than the risks covered by the use and maximum cultivation of transgenic crops. The practical use of transgenic crops may enhance the economy of developing country; therefore, in my opinion transgenic plants should be promoted in developing countries. Though, the impact of transgenic crops on the ecosystems should be monitored regularly to avoid the potential risk factors.

\section{Acknowledgements}

The Author is grateful to Prof. Ashok Kumar, 
School of Biotechnology, Banaras Hindu University, Varanasi, India for his guidance during preparation of manuscript.

\section{References}

Aerni, P. (1999). Public acceptance of genetically-engineered food in developing countries: the case of transgenic rice in the Philippine, AgBiotechNet, ABN o31, 4 pp. http://www.agbiotechnet.com/ reviews/ nov99/html/Aerni.htm.

Bell, H.A., Fitches, E.C., Down, R.E., Ford, L., Marris, G.C., Edwards, J.P. et al.. (2001). Effect of cowpea trypsin inhibitor (CpTI) on the growth and development of the tomato moth Lacanobia oleracae (Lepidoptera: Noctuidae) and on the success of the gregarious ectoparasitoid Eulophus pennicornis (Hymenoptera: Eulophidae). Pest Management Science, 57, 57-65.

Birch, A.N.E., Geoghean, I.E., Majerus, M.E.N., McNicol, J.W., Hackett, C.A., Gatehouse, A.M.R. et al.. (1999). Tri-trophic interactions involving pest aphid, predatory 2-spot ladybirds and transgenic potatoes expressing snowdrop lectin for aphid resistance. Molecular Breeding, 5, 75-83.

Bizily, S.P., Rugh, C.L. \& Meagher, R.B. (2000) Phytodetoxification of hazardous organomercurials by genetically engineered plants. Nature Biotechnology, $18,213-217$.

Buchmann, S.L. \& Nabham,G.P. (1996). The forgotten pollinators. Washington, D.C.: Island Press.

Cannell, R.Q. \& Hawes, J.D. (1994). Trends in tillage practices in relation to sustainable crop production with special reference to temperate climates. Soil Tillage Research, 30, 245 - 282.

Carpenter, J. \& Gianessi, L. (200o). Herbicide use on roundup ready crops. Science, 287 , 803-804.
CGIAR (1998) CGIAR acts on "terminator technology”. CGIAR News, December, p 3, also Nature (1998) 396, 11.

Crawley, M.J., Brown, S.L., Hails, R.S., Kohn, D.D. \& Rees, M. (2001). Transgenic crops in natural habitats. Nature, 409, 682-683.

Down, R.E., Ford, L., Woodhouse, S.D., Raemaekers, R.J.M., Leitch, B., Gatehouse, J.A. et al.. (2000) Snowdrop lectin (GNA) has no acute toxic effects on a beneficial insect predator, the 2-spot ladybird (Adalia bipunctata L.). Journal of Insect Physiology, 46, 379-391.

Elstrand, N.C., Prentice, H.C. \& Hancock, J.F. (1999). Gene flow and introgression from domesticated plants into their wild relatives. Annual Review of Ecology and Systematics, 30, 539-563.

Firbank, L.G., Dewar, A.M., Hill M.O., May, M.J., Perry, J.N., Rothery, P. et al.. (1999). Farm-scale evaluation of GM crops explained. Nature, 399, 727-728.

Gleba, D., Borisjuk, N.V., Borisjuk, L.G., Kneer, R., Poulev, A., Sarzhinskaya, M. et al.. (1999). Use of plant roots for phytoremediation and molecular farming. Proceedings of National Academy of Science U.S.A., 96, 5973 - 5977.

Griffiths, B.S., Geoghean, I.E. \& Robertson, W.M. (2000). Testing genetically engineered potato, producing the lectins GNA and ConA, on non-target soil organisms and processes, Journal of Applied Ecology, 37, 159-170.

Hansen Jesse, L.C. \& Obrycki, J.J. (200o). Field deposition of Bt transgenic corn pollen: lethal effects on the monarch butterfly. Oecologia, 125, 241-248.

Hilbeck, A., Meier, M.S. \& Raps, A. (2000). Review on non-target organisms and Btplants. EcoStrat GmbH, Zurich. 77 p. 
Hutchinson, G.E. (1965). The ecological theatre and the evolutionary play. New Haven, U.S.A: Yale Univ. Press.

James, C. (1988). Global review of transgenic crops, 1998. ISAAA Briefs No. 8, International Service for the Acquisition of Agri-biotech Applications, Ithaca, NY, USA. http://www.agbiotechnet.com/reports/ isaaa_briefs/Brief8.pdf

Jørgensen, H.B. \& Lövei, G.L. (1999). Tritrophic effects on predator feeding: consumption by the carabid Harpalus affinis of Heliothis armigera caterpillars fed on proteinase inhibitor- containing diet. Entomologia Experimentalis et Applicata, 93, 113-116.

Krattiger, A.F. (1997). Insect resistance to crops: A case study of Bacillus thuringiensis (Bt) and its transfer to developing countries, ISAAA Briefs No. 2, International Service for the Acquisition of Agri-biotech Applications, Ithaca, NY, USA. http://www. agbiotechnet.com/reports/isaaa_briefs/Brief2. $p d f$

Krebs, J.R., Wilson, J.D., Bradbury, R.B. \& Siriwardena, G.M. (1999). The second silent spring. Nature, 400, 611-612.

Losey, J.E., Rayor, L.S. \& Carter, M.E. (1999). Transgenic pollen harms monarch larvae. Nature, 399, 214.

Lövei, G.l. (2001). Ecological risks and benefits of transgenic Plants. New Zealand Plant Protection, 54, 93-100.

Lövei, G.L., Felkl, G., Broodsgaard, H.B. \& Hansen L.M. (2001). Environmental risks of insect -tolerant transgenic plants. 18th Danish Plant Protection Conference DJF Rapport nr, 41, 171-176.

Malone, L.A., Burgess, E.P.J., Gatehouse, H.S., Voisey, C.R., Tregida, E.L. \& Philip, B.A. (2001). Effects of ingestion of a Bacillus thuringiensis toxin and a trypsin inhibitor on honey bee flight activity and longevity. Apidologie, 32, 57-68.
Moffat, A.S. (1998). Toting up the early harvest of transgenic plants. Science, 282, 21762178.

Price, P.W., Bouton, C.E., Gross, P., Bruce, A.M., Thompson, J.N. and Weis, A.E. (1980). Interactions among three trophic levels: influence of plants on interactions between insect herbivores and natural enemies. Annual Review of Entomology, 11, 41-65.

Purrington, C.B. \& Bergelson, J. (1995). Assessing weediness of trangenic crops: industry plays plant ecologist. Trends in Ecology and Evolution, 10, 340-342.

Riddick, E.W., Dively, G. \& Barbosa, P. (1998). Effect of a seed-mix deployment of Cry3 A transgenic and non transgenic potato on the abundance of Lebia grandis (Coleoptera : Carabidae) and Coleomegilla maculata (Coleoptera : Coccinellidae). Annals of Entomology Society of America, $91,647-653$.

Saxena, D., Flores, S. \& Stotzky, G. (2000). Insecticidal toxin in root exudates from $\mathrm{Bt}$ corn. Nature, 402, 480.

Schuler, T.H., Potting, R.P.J., Denholm , I. \& Poppy, G.M. (1999). Parasitoid behaviour and $B t$ plants. Nature, 400, 825-826.

Skerritt, J. H. (200o). Genetically modified plants: developing countries and the public acceptance debate. AgBiotechNet, Vol. 2 February, ABNo4o.

Stewart, C.N. jr., All, J.N., Raymer, P.L. \& Ramachadran, S. (1997). Increased fitness of transgenic insecticidal rapeseed under insect selection pressure. Molecular Ecology, 6, 773- 779.

Vitousek, P.M., D’Antonio, C.M., Loope, L.L., Rejmanek, M. \& Westbrooks, R. (1997a). Introduced species: a significant component of human-caused global change. New Zealand Journal of Ecology, 21, 1-16. 
Vitousek, P.M., Mooney, H.A., Lubchenco, J. \& Melillo, J.M. (1997b). Human domination of Earth's ecosystems. Science, 277, 494499.

Watkinson, A.R., Freckleton, R.P., Robinson, R.A. \& Sutherland, W.J. (2000). Predictions of biodiversity response to enetically modified herbicide-tolerant crops. Science, 289, 1554-1557.
Wolfenbarger, L.L. \& Phifer, P.R. (200o). The ecological risks and benefits of genetically engineered plants. Science, 290, 20882093.

Wraight, C.L., Zangerl, A.R., Carroll, M.J. \& Berenbaum, M.R. (2000). Absence of toxicity of Bacillus thuringiensis pollen to black swallowtails under field conditions. Proceedings of National. Academy of. Science U.S.A., 97, 7700-7703.

\section{The Author}

Umesh Prasad Shrivastava is an Associate Psrofessor of Botany, T.R.M. Campus, Birgunj where he teaches cytogenetics, biotechnology and other branches of Botany for the last 20 years. He holds a Ph.D. in Biotechnology from Banaras Hindu University, Varanasi, India. He has published so far eight research papers in reputed international and national journals and a few are in a queue of publication. He has also published 13 sequences of gene in NCBI geneBank. His area of interest in research includes plant microbe interaction, molecular biology of microorganisms and bio-informatics.

Email: upshrivastava@gmail.com 